\title{
THE LIMITS OF CREATIVE APPROACH: CONDUCTING AN ORCHESTRA OF EMOTIONS IN THE DARKNESS
}

\author{
Ilze GRINFELDE ${ }^{1^{*}}$, Linda VELIVERRONENA ${ }^{2}$ \\ 1, 2 Vidzeme University of Applied Sciences, Institute of Social, Economic and Humanities Research, \\ Cèsu str. 4, Valmiera, LV-4201, Latvia
}

Received 31 May 2017; accepted 22 November 2018

\begin{abstract}
Soviet period has left behind number of uncomfortable, also unwanted heritage sites in Eastern Europe countries that are sensitive, emotionally loaded and easy to communicate neither for locals nor tourists. Such a site is Committee for State Security Building that functions as a museum of Communist regime victims in Riga, Latvia. The research discusses the balance between creativity and authentic simplicity in the designing visitors' on-site experience in dark tourism objects. The aim of the study is to explore visitors' emotions during visit to Committee for State Security Building in Riga and the role of a creative tourism product design in stimulating emotions. Visitors' comments about their visit to the Committee for State Security Building on TripAdvisor were used as the main data source. The research results confirm walking tour in Committee for State Security Building generates memorable impressions and contrast the opinion that new layers of creativity to this dark tourism product would satisfy and entertain customer. The Committee for State Security Building in Riga is an example where creative tourism product design does not have a significant impact on the emotional experience of visitors because main sources of visitors' experience are high quality performance of tour guides and their rich knowledge, personal stories, authentic atmosphere and interior of the building.
\end{abstract}

Keywords: dark tourism, creativity, emotions, tourism product design, visitor experience, visitor motivation.

\section{Introduction}

Creativity has become a synonym of new models of production and consumption, adding the new values and elements that contribute to the touristic growth of a locality. It is a sign of contemporary thinking that contributes as revitalizer for some regions, destinations and sites. Creativity can promote a new way of tourism opening the door to a variety of themes, activities, experiences, combined with different levels of participation of tourists from perspective of both - service providers and visitors (Messineo, 2012). In terms of tourism as multidimensional phenomena creativity aspect is vague often associated with new layers,

*Corresponding author. E-mail: ilze.grinfelde@va.lv 
products, adding ideas, however, risk is hidden in non-critical attitude which could end up in lost authenticity, identity and core values.

It is obvious that recently the cultural tourism market is being over-flooded with new attractions, cultural routes and heritage centers that results in the serial reproduction and adaptation of already used ides, approaches in experience design of culture in different destinations. Ongoing process results in superficial and non-critical attitude from visitors and suppliers start to concentrate on new, lower value markets. Consequently, customer becomes more demanding and the trend of skilled consumption in post-modern society with aim to form identity and to acquire cultural capital (Richards, 2010; Richards \& Wilson, 2006).

Developers of contemporary tourism products are concerned how to make their products more attractive and competitive, literally emphasizing creativity in product communication; however, uncomfortable heritage based tourism products do not follow the same track due to sensitivity issues and its aim to educate, construct and pass-on collective memory. A number of memory sites (such as memorials, expositions, museums) have been established in the former Soviet states to honor and remember the victims of the Communist regime (CR). These sites are significant for local population and recently have been recognized as heritage that could be utilized in tourism - as a dark tourism product. Nevertheless, there are still only a few cases where a particular "unwanted" heritage has been packed as tourism product.

Not necessarily there is a need for over-creative transformation and uncomfortable heritage sites might be the case where creative tourism product design might be evaluated differently. For example, Avital Biran, Yaniv Poria and Gila Oren claim that in the context of dark tourism it entails not only natural fascination for death, in some research mentioned as primary reason, but also a quest for authentic experiences (2011). Dark tourism as rather new form of tourism often causes moral and ethical dilemmas for governmental bodies and managers (Minić, 2012).

Post-Soviet heritage is more often used in dark tourism context in many cities of Eastern Europe and one such heritage site is Committee for State Security (in Russian: Komitet gosudarstvennoy bezopasnosti) Building (CSSB) that functions as museum of CR victims in Riga, Latvia. Uncomfortable heritage in post-Soviet countries has recently aroused researchers' interest in different fields, also in tourism (Caraba, 2011; Ivanov, 2009; Isaac \& Budryte-Ausiejiene, 2015; Velmet, 2011) and we join the discussion by exploring the case of the Committee State Security Museum (CSSM) in Riga from the perspective of visitors. So far, studies of CR associated heritage sites in a dark tourism context are under researched in the Baltic states and other Eastern Bloc countries due to its sensitivity, high emotional load, and temporal proximity, shortage of information have. The previous papers have been mostly descriptive and focused on public memory, politics and the visualization of a particular heritage to implicate a sense of socialism.

The CSSB in Riga was opened to visitors only a few years ago and gained immediate popularity in terms of visitors. The authenticity of the museum is undisputable as it is located in the old CSS headquarters and has original interiors together with the number of repressed victims that define the site as one the darkest in Latvia. The CSSB is an affiliate of the Museum of the Occupation of Latvia (MOL) and there is limited experience in introducing visitors to such an uncomfortable heritage. The CSSM in Riga has been selected as a case, because it 
is the only CSSM in the Baltic states, which has not undergone any changes to accommodate the museum expositions, and therefore it exposes the highest level of authenticity, which is essential factor in the context of emotions.

The research related to the CSSB and its work with visitors can be helpful for dark tourism sites to find balance between creativity and authentic simplicity in the designing visitors' onsite experience. The aim of the study is to explore visitors' emotions during visit to CSSB in Riga and the role of a creative tourism product design in stimulating emotions.

The main data source for the analysis of visitors' on-site experience and emotions are post-visit comments on TripAdvisor. Such a method for data collection was chosen because technology-mediated communication has a great impact on satisfaction, trust building, commitment and future intentions. Content analysis was chosen as the main data analysis method. Additionally, the internet as a socio-technical system is virtually in every sphere of our social lives offering different modes of communication, sharing, performing and displaying of emotion ingredients with a high interaction level and research on displays of public emotion on the internet has emerged and become a challenging field capturing the interest of psychologists, computer science researchers, communication experts etc. (Benski \& Fisher, 2014; Küster \& Kappas, 2014).

The article is structured as follows: at the beginning, we will present a review of the CSSB in the context of dark tourism. Then we move on to a literature review of the role of emotions in tourist satisfaction before describing and analyzing the research results.

\section{The Committee State Security Building as a dark tourism site}

Dark tourism - travelling to commoditized sites of death and suffering that have been packaged up and constructed into performative leisure experiences for tourism consumption has been recognized as a commercial phenomenon for approximately twenty years (Lennon \& Foley, 2000; Sharpley \& Stone, 2009). Thus it is still a comparatively new sphere of discussions for academics and growing in practice, although still without comprehension (Podoshen, Andrzejewski, Venkatesh, \& Wallin, 2015) due to the controversial nature of its resources. The concept of dark tourism resources includes both tourism and urban planning perspectives reflected in the labels of "uncomfortable", "dissonant", "displaced", "unwanted", "heritage that hurts" or "traumascapes" (Convery, Corsane, \& Davis, 2014; Macdonald, 2006; Merrill, 2010; Sather-Wagstaff, 2011; Tumarkin, 2005; Tunbridge \& Ashworth, 1996).

Sam Merrill defines traumascapes as

"a place where the traumatic past hangs like tension in the warm stagnant air, a place where tragic events lurk intangibly, play on emotions, imaginations and fears and yet, where, due to necessity, the past which causes these tensions, emotions, imaginations and fears, is codified, put to the back of one's mind, forgotten or never truly revealed in the first place. It is a subterranean landscape that through necessity lives alongside its traumatic past, a past related to war, terror and disaster" (2010, p. 68)

and many of these aspects can be observed in the CSSB in Riga. The core element of tourism product is guided excursion in the basement of CSSB where prisoners were kept and it is available on scheduled times. The story of tour guides is rational and based on personal stories; 
however, without drama. The tour ends in the execution chamber where visitors watch the fragment of massacring from the Polish movie Katyń (2007) by Andrzej Wajda. Free of charge and fact based exposition is available in opening hours; however, with limited intentions to make emotional impact to visitor without knowledge of the specific historical context.

The basic conceptual framework of dark tourism products is known as the "Dark Tourism Spectrum", and it helps to identify and locate a particular product by specific features. The following approach of "Seven Dark Suppliers" (dark fun factories; dark exhibitions; dark dungeons; dark resting places; dark shrines; dark conflict sites; dark camps of genocide) illustrates the relationship of the provider-consumer in more detail (Stone, 2006).

The CSSB in Riga belongs to the darkest part of the dark tourism spectrum concept as it is an actual place of death and suffering related to the ideology and political power of the Soviet period. The CSS of the Latvian Soviet Socialist Republic occupied a special place in the implementation of repressions in Latvia. The CSS was located in the very Centre of the capital Riga in a beautiful building designed as a rental house with shops (Griškeviča, Garda, \& Otto, 2015). According to the website of MOL, behind its walls, CSS officials imprisoned, tortured, and during 1940-1941 also killed opponents of the Soviet regime (SR). The building was adapted to the needs of repressive functions: imprisonment cells were built in the cellar where opponents were kept in overcrowded rooms, and a cell was established for shooting prisoners. The CSS's working methods changed a little after Joseph Stalin's death in 1953 when physical torture was replaced by psychological torture.

CSS activities in Latvia ended in 1991 when the Supreme Council of the Republic of Latvia declared the Communist Party of Latvia unconstitutional and made the decision to terminate the Soviet security bodies in Latvia (likumi.lv, 1991). In the 1990s, the building was owned by the state and part of it was used by the Latvian State Police, then for several years it stood abandoned until it was opened to the visitors in 2014 as the MOL implemented a short term project so that people could walk through Cheka (The All-Russian Extraordinary Commission), cellars and to see exhibitions individually or in guided tours. Later it was decided that its basement and first floor should be re-opened to the public as a permanent exhibition as part of the MOL. The interior of this space has not been renovated and is kept authentic. Since re-opening, diverse audiences have visited the museum - from victims of the regime who had been imprisoned there to groups of students and foreigners for whom the brutality of the SR may come as eye-opener.

Following Philip Stone (2006), it can be said its approach in interpretation is history centered: it is not commercially oriented, its location is original and its infrastructure fully authentic with no specific arrangements for tourists.

\section{The role of emotions in dark tourism}

We cannot imagine life without emotions anywhere - this is how we survive, and emotions play the central role in defining memorable experiences in tourism (Plutchik, 2001; Scherer, 2005). Attending dark tourism sites is a way of triggering emotions (Timm Knudsen, 2011) and it is important to explore emotional link between tourists and the space visited to better understand and manage heritage site (Poria, Butler, \& Airey, 2004). 
Girish Prayag, Sameer Hosany, Birgit Muskat and Giacomo Del Chiappa (2017) have reviewed previous emotion related studies in tourism and have summarized that tourists' emotional experiences play role at every phase of tourist behavior - the motivation to travel, the choice of a destination, on-spot experience, post-consumption satisfaction. Authors' empirical data analysis re-confirms that specific emotions are significant predictors of attitudinal and behavioral outcomes (Prayag et al., 2017). In this study we argue the significance of emotions from two perspectives - on one had as predictor of attitude and behavior of tourist (e.g. the will to recommend tourist product for other), and on other hand, the dark tourism visitors may encounter emotions that otherwise rarely come their way (Korstanje \& Ivanov, 2012).

In the 20th century alone more than 90 definitions of emotions were proposed and researchers continue to search for the best way how to classify and interpret emotions instead of censoring themselves (Plutchik, 2001). According to Klaus Scherer, emotions can be defined as

"an episode of interrelated, synchronized changes in the states of all or most of the five organismic subsystems in response to the evaluation of an external or internal stimulus event as relevant to major concerns of the organism" (2005, p. 697),

they are short-lived, intense, and conscious (1987). Emotions are not merely individual and subjective but also socially divulging. Emotions involve sensory and cognitive aspects as well as social norms (feeling rules) and performative (displaying rules) aspects (Hochschild, 1990).

The consumption of dark tourism products involves a wide spectrum of interpretations from entertainment to tragedy and, as Stuart Moss (2009) suggests, even entertainment potentially causes both positive and negative effects. Similarly, Jeroen Nawijn and Marie-Christin Fricke (2015) argue that a visit to a dark tourism site can create a co-activation or triggering of both positive and negative emotions. However, previous dark tourism studies reveal that negative emotions (disgust, fear, anger, sadness, etc.) are predominant. Olivier Luminet, Patrick Bouts, Frédérique Delie, Anthony S. R. Manstead and Bernard Rimé (2000) suggest that a traumatic experience generates intrusive, repetitive thoughts and images related to the emotion-provoking situation. It is a natural proclivity to be fascinated by traumatic and even tragic episodes.

Emotion studies are not very common in dark tourism research. They are based on particular cases that differ by nature (Stone \& Sharpley, 2008); however, the dark tourism experience ascertains empathy and/or emotion on the part of the visitor that is heightened by the character of the site in terms of time and place (Miles, 2002).

It is more and more common - a rationalized display of emotions as a part of civilization process in digital late modern societies. The social sharing of emotions is an adaptive response to situations of distress also in the context of dark tourism (Luminet et al., 2000; Micallizzi, 2014). It helps to overcome such difficulties as sharing emotions face to face, time, space, experience barriers as social life has become more fragmented.

\section{Methods}

Emotions are significant predictors of attitudinal and behavioral outcomes (Prayag et al., 2017) and thus this study measures the emotions of the visitors, so that it could be used to determine their satisfaction with on-site visit to CSSB. Comments posted on TripAdvisor are 
used as data source to identify main elements that have had impact on visitors' on-site experience. Both analysis allow to make conclusions on visitor's emotional experience, satisfaction and need to establish more creative approach to design visit to CSSB as dark tourism product.

Dennis Küster and Arvid Kappas (2014) suggest three ways to measure emotions on the Internet that are not mutually excluding: 1) to study large amounts of emotional content on the Internet; 2) to ask sharing emotional responses online; 3) to study bodily responses unobtrusively in order to measure emotions. All methods could complement each other; however, there are limitations, such as subjectivity, missing context, difficulties to detect or verbalize emotions and the fact that some subjects contribute large amount of data in comparison to others (Küster \& Kappas, 2014). Despite the above mentioned, it is important to stress that the Internet as an environment influences only the way of expression, not the experience that creates the emotions itself (Jakoby \& Reiser, 2014). Qualitative narrative aspects (general characteristics of posts, dynamics, etc., tetcopography of conversation, profiles of participants) and quantitative content analysis with a specific focus on emotions are the main research methods represented in recent studies (Micallizzi, 2014).

This study analyses comments displayed by visitors of the CSSB on the TripAdvisor platform using content analysis to analyze the content created by users. According to TripAdvisor (2018) it is globally the largest travel community with 490 million individual visitors and 702 million reviews. This media was selected because it displays the highest number of visitors' reviews about the CSSM. The initial data base consists of 290 comments posted during the period from May 2014 until January 2016. For analysis, we used 200 comments excluding those written in other languages than English due to doubts about the quality of automatic translation systems. The data were analysed with qualitative content analysis to identify categories of emotions. According to Klaus Krippendorff (2004), content analysis is a research technique for making replicable and valid inferences from texts to the contexts of their use. The data were reviewed and grouped into categories through open coding (Corbin \& Strauss, 1990). According to Juliet Corbin and Anselm Strauss (1990), in open coding events/actions/ interactions are compared with others for similarities and differences, and they are also given conceptual labels. The aim of grouping data was to reduce the number of categories. Content analysis was implemented in three stages. In the first stage, we identified the words and expressions describing visitors' emotions. Robert Plutchik's wheel of emotions (Plutchik \& Kellerman, 1980) and Scherer's (2005) approach were used to perform the initial coding of data and to identify visitors' emotions. The specific nature of emotions displayed in particular cases challenged the coding process, therefore, we combined different approaches to label and code data with maximum accuracy. The emotions were expressed in different forms:

1. Direct identification of emotion - "I felt sad";

2. Physiological symptoms - "The hairs on my arms stood on end", "My heart went faster", "It was hard to breathe";

3. Metaphors - "Not pleasant aftertaste", "Blowing of steam", "I was totally frozen" or other descriptive texts (Plutchik, 2001; Scherer, 2005).

We created the coding guidelines relating each of these descriptors with emotions experienced by the visitors. The facial or motoric expressions were not used in comments. The first stage analysis allowed to identify 25 emotions in the clusters of feelings to implement 
the frequency count of emotions. Data coding was challenging process and demanded a lot of discussions and several rounds of re-coding until the final code guidebook was developed.

In the next stage, we initially applied James A. Russell's (1980) circumplex model of affect, which allows to classify emotions integrating dimensions of valence and arousal, however, interim results generated more questions than answers due to emotions that cannot be strictly placed in a model. In this case, we used circumplex model of core affect (CMCA) with product relevant emotions (PRE) designed by Pieter M. A. Desmet (2008), adapted from the abovementioned Russell study that broadens the view on "blended emotions". The CMCA with PRE combines two-dimensions - the valence (from unpleasant to pleasant) with physiological arousal (from calm to excitement). In this concept experience of core affect is a single integral blend of those two dimensions, describable as a position on the circumflex (Desmet \& Hekkert, 2007). The second stage coding process allowed us to group the emotions experienced by visitors of the CSSB into 8 clusters: activated pleasant, activated unpleasant, deactivated pleasant, deactivated unpleasant, blended activated pleasant and unpleasant, blended deactivated pleasant and unpleasant, transition form from pleasant active to de-active and transition form from unpleasant active to de-active.

Another round of content analysis was implemented to identify the elements that made experience of visitors - close reading identified exhibition, space (building itself and atmosphere), tour guide as the key elements. The context of the key elements was searched in the TripAdvisor comments to identify if these elements were evaluated positively or negatively and to main factors of tourist experience and the role of creativity.

We are aware there are certain methodological limitations for this research. The method of data collection we used does not allow to explore the transformation of visitors' emotions during the visit, so the results of the research focus to the fixed emotions at the moment of writing the comment in TripAdvisor. The TripAdvisor as a data source does not generate a complete picture as it does not reflect the physical manifestations of emotions such as facial expressions, voice intonation and so on (apart from rare cases when an author has described it himself/herself); however, there are arguments in favor of using the Internet as a data source. For instance, Daantje Derks, Agneta H. Fischer and Arjan E. R. Bos (2008) claim that social non-presence allows the display of negative emotions despite common social norms. Thus there is always space for debate on apt methodology how to measure visitor emotions on Internet.

\section{Results and data analysis}

In this study, visitor-created content online on TripAdvisor was used to explore the spectrum of emotions provoked by the visit to an uncomfortable heritage site: the CSSB in Riga. Dark tourism objects related to historically significant events can provoke high-level visitor engagement (Nawijn, 2016) and learning, therefore, instead of immediate on-the-spot emotional displays, we focused on more saturated post-visit emotions.

The average TripAdvisor evaluation for CSSB is 4.4 stars given by authors of the comments selected for analysis. The analysis of emotions expressed online presented that CSSB tour and exhibition educates, shocks, saddens, takes up memories and provides a wide spectrum of emotions and very few remains indifferent. 
At the first stage of analysis, according to the code guide, we identified 25 main emotions shared online by the visitors of the CSSB in Riga. Table 1 reflects the results of the quantitative content analysis - emotions were recognized 374 times in 200 comments. It is important to note that the majority of the comments contained emotional components, while some were completely rational showing a pragmatic interest and describing working hours, prices and other practicalities.

Table 1. Frequency count of emotions recognized in the TripAdvisor comments posted by visitors of the Committee State Security Building in Riga (source: created by authors)

\begin{tabular}{|l|l|l|c|}
\hline \multicolumn{2}{|c|}{ Emotion } & Count & \multicolumn{2}{c|}{ Emotion } & Count \\
\hline \multicolumn{2}{|c|}{ Being touched } & & 418 \\
\hline Compassionate & 63 & Rejective & 4 \\
\hline Disgusted & 44 & Overwhelmed & 4 \\
\hline Stressed/felt tension & 29 & Disappointed & 3 \\
\hline Thoughtful & 17 & Relieved & 3 \\
\hline Sad & 14 & Shocked & 2 \\
\hline Angry & 13 & Confused & 2 \\
\hline Hopeful & 13 & Admiration & 1 \\
\hline Interested & 11 & Critical & 1 \\
\hline Grateful & 9 & Excited & 1 \\
\hline In fear & 5 & Distant & 2 \\
\hline Disillusioned & 5 & Surprised & \\
\hline Regretful & 4 & Enthusiastic & \\
\hline
\end{tabular}

"Being touched" was the most dominant emotion experienced by 118 visitors out of 200. It was often related with showing compassion for the victims of the CSS, which was the second most frequently mentioned emotion. The third most often mentioned emotion in the posts was "feeling disgust" - visitors used such words as "horrific", "awful", "brutal", "inhumane" to describe both the CSS headquarters and the Soviet occupation regime in Latvia. Quite a few visitors described the site as an "eye opener" and their previous illusions of the world that had been deconstructed as a result of the visit. Some people were disappointed because the illustration of history represented by the site was not "as bad" as they had seen in other dark tourism objects. For many people the visit to this site had also generated a deeper interest in the topic and provoked thoughts of how it was possible for such violence to emerge in a relatively recent history. Widespread emotions displayed by the visitors at dark tourism sites in general are related to feeling tension and/or stress during or after the visit and it was also confirmed by this CSSB study.

It is worth mentioning the emotion of "hope" experienced by the visitors. It refers to the hope that some visitors had: that the CSSB would remain available to the visitors because the history it represents makes it a "must see" object. One of the strongest emotions experienced by the visitors was "anger" - people encouraged others to fight against oppression so that history would never repeat itself. The list contains other emotions quite typical for dark 
tourism sites, such as gratefulness that the visitor has not had to endure the horrors personally, and a rejection of history represented by the object. In the second stage of analysis, data were categorized according to the CMCA (Desmet, 2008). Figures 1 and 2 represent both the spectrum and quantity of activated, deactivated and blended (pleasant/unpleasant and activated/deactivated) emotions displayed by visitors of the CSSB in Riga. Sectors B and D represent pleasant emotions, $\mathrm{A}$ and $\mathrm{C}$ unpleasant ones. Sectors A1 and B1 reflect blended activated emotions, $\mathrm{C} 1$ and D1 blended deactivated. B-1 and D-1 are representing a transition form from pleasant activated to deactivated, A-1 and C-1 a transition form from unpleasant activated to deactivated. Figure 1 shows how the highest number of diverse emotions are represented in the sectors of blended emotions - A1/B1 and A-1/C-1.

Figure 2 below displays the combined result of frequency count (Table 1) and The spectrum of CSSB visitors' emotions mapped in accordance to adapted CMCA.

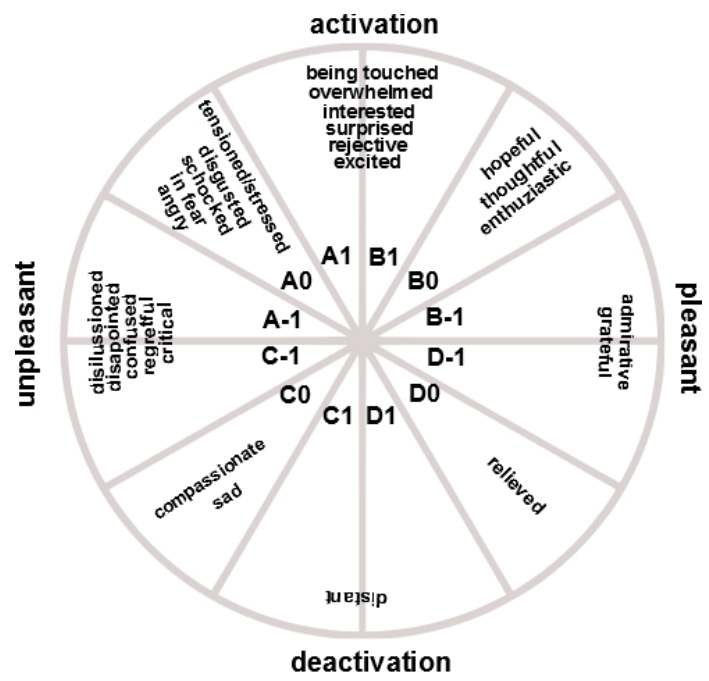

Figure 1. The spectrum of Committee State Security Building visitors' emotions mapped in accordance to the adapted circumplex model of core affect (Desmet, 2008) (source: created by authors)

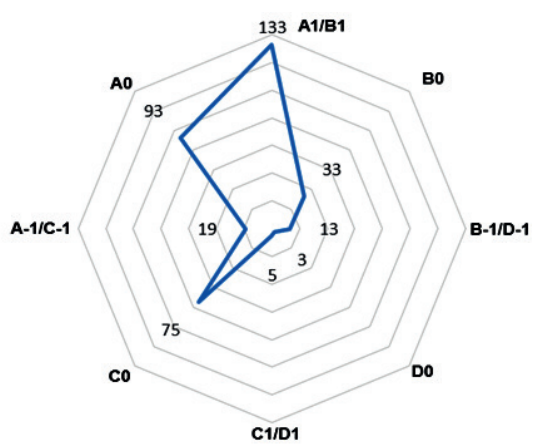

Figure 2. The frequency count of visitors emotions in circumplex model of core affect (source: created by authors) 
In general, the CSSB visit provokes a wide spectrum of varied active and unpleasant emotions. To some extent comments as our data source explain the presence of active emotions - people willing to make an effort to comment online have been compelled to do so because of the strong emotions experienced in the CSSB.

The comments expressed by visitors allow to identify some typical connections between emotions - the most widespread is a triangle of emotions "being touched", "compassion" and "disgust". It ties together unpleasant and pleasant activated emotions with unpleasant deactivated emotions thus claiming that dark tourism places produce rather active and unpleasant emotions. Positive emotions of visitors to the CSSB were mostly linked to gratitude to the museum staff and a recognition of personal gains, e.g. a reconsideration of one's values.

Basic frequency count highlights the role of tour guides during visit to the CSSB, and most frequently visitors refer to the tour guides extensive knowledge of historical facts, and even more often prize passion and inspirational nature of guides. The personal testimonies, told both by ex-prisoners on videos and tour guides, are powerful instruments to intensify emotions and thus to provoke a reconsideration of visitors' values and attitudes. The untouched space, authentic interior as it used to be in past also heavily impact the on-site experience of visitors. Only few (6) visitors do not prize the authenticity of the site and their comments lead to think they would prefer less authentic and more creative approach towards the exhibition. Neutral comments refer to the wide textual information which - a part of the exhibition (see Table 2).

Table 2. Frequency count of product design elements from the perspective of Committee State Security Building visitors (source: created by authors)

\begin{tabular}{|l|c|c|}
\hline \multirow{2}{*}{} & \multicolumn{2}{|c|}{ The elements of visitor experience } \\
\cline { 2 - 3 } & Positive context & Negative context \\
\hline Reference to tour guide (total number) & 53 & 1 \\
\hline Personal stories by tour guide & 8 & \\
\hline Knowledge, facts provided by a tour guide & 23 & 1 \\
\hline A passion, fascinating tour guide & 31 & \\
\hline Reference to building (total number) & 44 & 2 \\
\hline Authentic space, living conditions of those days & 39 & 6 \\
\hline Other & 6 & 6 \\
\hline Personal video testimonies & 6 & \\
\hline Exhibition & & \\
\hline
\end{tabular}

We can conclude the wide spectrum of visitor emotions have been induced mostly by the high class tour guide performance and authentic space.

\section{Conclusions and discussions}

Provision of memorable and authentic tourist experiences are challenging all tourism and leisure sector stakeholders. In the field of research, relatively little is known about service 
providers influence on the tourist experience through interaction, customization and service design (Zatori, Smith, \& Puczko, 2018), however, the study results confirm walking tour in CSSB generates authentic and memorable experience. It is in agreement with Elizabeth Wood and Kiersten F. Latham (2016) that sometimes daring, imaginative organization, balance and simplicity can stimulate strong, active feelings, emotions. Additionally, the daily pace stimulates desire to simplicity and sometimes simplicity is considered as a form of creative product design element (Visit England, 2013).

The authentic environment of the CSSB exhibition educates, shocks, saddens, takes up memories and provides a wide spectrum of emotions - depending on the visitor's previous experience, attitude and knowledge of the CSS's work. For the visitors the visit was emotionally difficult but still valuable. The fact that majority of the visitors' labels CSSB as a "must see" experience shows their expectations have been met. Even more - visitors mostly have experienced active emotions, therefore, we can assume that visitors are likely to search additional information about the topic and to share their experiences. How this "must see" effect has been achieved?

Referring to the elements that have created their experience, TripAdvisor users mention the high quality performance of tour guides and their rich knowledge, personal stories. In special interest tourism there is tendency to employ skilled staff (Minić, 2012) and the guides also act as mediators, of the tourist experience (Weiler \& Walker, 2014; Diaz-Soria, 2017). As result the visitors established a personal connection with the sufferings of the people previously imprisoned in the Corner House. Also, external factors such as physical experience elements, human interaction and situational factors have a crucial influence (Walls, Okumus, Wang, \& Joon-Wuk Kwun, 2011), in this case it is authentic atmosphere and interior of the building. On-site experience has been discussed in aspect of authenticity by Inmaculada Diaz-Soria (2017) as one of the crucial outcomes. Visitor experience entails subjective, personal and emotional aspects and various personal resources (e.g. interest, skills, attitude) contribute in to experience formation (O'Dell, 2005; Chen, Prebensen, \& Uysal, 2014). According to B. Joseph Pine II and James H. Gilmore (2008), authenticity in the context of tourism suppliers is perceived as an essential asset of firms that provide services for consumers, which are not only satisfied with low costs and high quality, but also seek for genuine experiences' (Pine \& Gilmore, 2008).

Rather few people consider this dark tourism site as tourist entertainment. In fact, the research results contrast the opinion that it is necessary to add new layers of creativity to this dark tourism product to satisfy and entertain contemporary customer. According to VisitBritain (Visit England, 2013), the daily pace stimulates desire to simplicity sometimes even considered as a form of creative product design element. The CSSB in Riga is an example where creative tourism product design does not have a significant impact on the emotional experience of visitors.

Instead of adding creative layers to this tourism product, it is rather worth to discuss the re-designing the tour. The CSSM tour is emotionally difficult for visitors and the dark tourism site is to some extent responsible for the consequences it has provoked. We are aware that capability to monitor one's own and others' feelings and emotions, to distinguish them depends on individual's emotional intelligence (Salovey \& Mayer, 1990) and that suggests the guided tour could be re-designed in a way that visitors have some time to recover and have 
some rather moderate experience before getting out of the museum - should the museum consider establishing a separate space that would serve as a "emotional transition point" to present-day reality after an emotionally (over)loaded visit in the past?

Authenticity and storytelling encourage visitors to experience intense emotions and think about this topic much more deeply than a site simply giving technical facts or other nonpersonalized information. On the basis of this, we recommend museums to continue and strengthen the practice of sharing personal stories as it helps all the engaged parties - it helps visitors to increase their connection with the site, to connect anonymous history events with real persons, and to some extent it encourages a re-evaluation of personal values and personal identity construction.

This dark tourism product is already designed in a way that visitor experience entails subjective, personal and emotional aspects and various personal resources (e.g. interest, skills, attitude) contribute in to experience formation (O’Dell, 2005; Chen et al., 2014) and in cases like this simplicity even can be considered as a form of creative product design element.

\section{References}

Benski, T., \& Fisher, E. (2014). Introduction: investigation emotions and the internet. In T. Benski \& E. Fisher (Eds.), Internet and emotions (pp. 1-16). Series: Routledge Studies in Science, Technology and Society. New York, London: Routledge, London: Routledge.

Biran, A., Poria, Y., \& Oren, G. (2011). Sought experiences at (Dark) heritage sites. Annals of Tourism Research, 38(3), 820-841. https://doi.org/10.1016/j.annals.2010.12.001

Caraba, C. C. (2011). Communist heritage tourism and red tourism: concepts, development and problems. Cinq Continents, 1(1), 29-39.

Chen, J. S., Prebensen, N. K., \& Uysal, M. (2014). Dynamic drivers of tourist experiences. In N. K. Prebensen, J. S. Chen, \& M. S. Uysal (Eds.), Creating experience value in tourism (pp. 11-21). London: CAB International.

Convery, I., Corsane, G., \& Davis, P. (Eds.). (2014). Displaced heritage: responses to disaster, trauma, and loss. Series: Heritage Matters. P. G. Stone, P. Davis, \& Ch. Whitehead (Series Eds.). Woodbridge: The Boydel Press.

Corbin, J., \& Strauss, A. (1990). Grounded theory research: procedures, canons, and evaluative criteria. Qualitative Sociology, 13(1), 3-21. https://doi.org/10.1007/BF00988593

Desmet, P. M. A. (2008). Product emotion. In H. N. J. Schifferstein \& P. Hekkert (Eds.), Product Experience (pp. 379-398). San Diego: Elsevier. https://doi.org/10.1016/B978-008045089-6.50018-6

Desmet, P., \& Hekkert, P. (2007). Framework of product experience. International Journal of Design, $1(1), 13-23$.

Derks, D., Fischer, A. H., \& Bos, A. E. R. (2008). The role of emotion in computer-mediated communication: a review. Computers in Human Behavior, 24(3), 766-785. https://doi.org/10.1016/j.chb.2007.04.004

Diaz-Soria, I. (2017). Being a tourist as a chosen experience in a proximity destination. Tourism Geographies, 19(1), 96-117. https://doi.org/10.1080/14616688.2016.1214976

Griškeviča, U., Garda, K., \& Otto, M. (2015). Pastaigas pa neparasto Rīgu. Rīga: Zvaigzne ABC.

Hochschild, A. R. (1990). Ideology and emotion management: a perspective and path for future research. In Th. D. Kemper (Ed.). Research agendas in the sociology of emotions (pp. 117-143). Albany: State University of New York Press. 
Isaac, R. K., \& Budryte-Ausiejiene, L. (2015). Interpreting the emotions of visitors: a study of visitor comment books at the Grūtas Park Museum, Lithuania. Scandinavian Journal of Hospitality and Tourism, 15(4), 400-424. https://doi.org/10.1080/15022250.2015.1024818

Ivanov, S. H. (2009). Opportunities for developing Communist heritage tourism in Bulgaria. Tourism, 57(2), 177-192.

Jakoby, N. R., \& Reiser, S. (2014). Grief 2.0: Exploring virtual cemeteries. In T. Benski \& E. Fisher (Eds.), Internet and emotions (pp. 65-79). Series: Routledge Studies in Science, Technology and Society. New York, London: Routledge, London: Routledge.

Korstanje, M. E., \& Ivanov, S. H. (2012). Tourism as a form of new psychological resilience: the inception of dark tourism. Cultur: Revista de Cultura e Turismo, 6(4), 56-71. https://doi.org/10.2139/ssrn.2168400

Krippendorff, K. (2004). Content analysis: an introduction to its methodology. Thousand Oaks, London, New Delhi: SAGE Publications.

Küster, D., \& Kappas, A. (2014). Measuring emotions in individuals and internet communities. In T. Benski \& E. Fisher (Eds.), Internet and emotions (pp. 48-63). Series: Routledge Studies in Science, Technology and Society. New York, London: Routledge.

Lennon, J., \& Foley, M. (2000). Dark tourism: the attraction of death and disaster. London and New York: Continuum.

likumi.lv. (1991). Par PSRS valsts drošǐbas iestāžu darbības izbeigšanu Latvijas Republikā. Retrieved from https://likumi.lv/doc.php?id=68765

Luminet, O., Bouts, P., Delie, F., Manstead, A. S. R., \& Rimé, B. (2000). Social sharing of emotion following exposure to a negatively valenced situation. Cognition and Emotion, 14(5), 661-688. https://doi.org/10.1080/02699930050117666

Macdonald, Sh. (2006). Undesirable heritage: fascist material culture and historical consciousness in Nuremberg. International Journal of Heritage Studies, 12(1), 9-28. https://doi.org/10.1080/13527250500384464

Merrill, S. (2010). War, terrorism \& disaster beneath: The London Underground as a traumascape. In S. Merrill \& L. Schmidt (Eds.), A reader in uncomfortable heritage and dark tourism (pp. 59-72). Cottbus: BTU Cottbus.

Messineo, E. (2012). Tourist creative processes and experiences in the European cultural itinerary "The Phoenicians' Route". Journal of Tourism Consumption and Practice, 4(2), 41-54.

Micallizzi, A. (2014). Anger, pain, shame, and cyber-voyeurism: emotions around E-Tragic events. In T. Benski \& E. Fisher (Eds.), Internet and emotions (pp. 193-210). Series: Routledge Studies in Science, Technology and Society. New York, London: Routledge.

Miles, W. F. S. (2002). Auschwitz: museum interpretation and darker tourism. Annals of Tourism Research, 29(4), 1175-1178. https://doi.org/10.1016/S0160-7383(02)00054-3

Minić, N. (2012). Development of "Dark" tourism in the contemporary society. Journal of Geographical Institute Cvijic, 62(3), 81-103. https://doi.org/10.2298/IJGI1203081M

Moss, S. (2009). Thrillertainment. In S. Moss (Ed.), The entertainment industry: an introduction (pp. 227-247). London: CAB International. https://doi.org/10.1079/9781845935511.0227

Nawijn, J. (2016). Positive psychology in tourism: a critique. Annals of Tourism Research, 56, 151-153. https://doi.org/10.1016/j.annals.2015.11.004

Nawijn, J., \& Fricke, M.-Ch. (2015). Visitor emotions and behavioral intentions: the case of Concentration Camp Memorial Neuengamme. International Journal of Tourism Research, 17(3), 221-228. https://doi.org/10.1002/jtr.1977

O'Dell, T. (2005). Experiencescapes: blurring borders and testing connections. In T. O’Dell \& P. Billing (Eds.), Experiencescapes: tourism, culture, and economy (pp. 11-33). Copenhagen: Copenhagen Business School Press. 
Pine, II B. J., \& Gilmore, J. H. (2008). The eight principles of strategic authenticity. Strategy \& Leadership, 36(3), 35-40. https://doi.org/10.1108/10878570810870776

Plutchik, R. (2001). The nature of emotions. American Scientist, 89(4), 344-350. https://doi.org/10.1511/2001.4.344

Plutchik, R., \& Kellerman, H. (Eds.). (1980). Emotion: theory, research, and experience. Vol. 1: Theories of Emotion. New York: Academic Press, Inc.

Podoshen, J. S., Andrzejewski, S. A., Venkatesh, V., \& Wallin, J. (2015). New approaches to dark tourism inquiry: a response to Isaac. Tourism Management, 51, 331-334.

https://doi.org/10.1016/j.tourman.2015.05.008

Poria, Y., Butler, R., \& Airey, D. (2004). The meanings of heritage sites for tourists: the case of Massada. Tourism Analysis, 9(1-2), 15-22. https://doi.org/10.3727/1083542041437549

Prayag, G., Hosany, S., Muskat, B., \& Del Chiappa, G. (2017). Understanding the relationships between tourists' emotional experiences, perceived overall image, satisfaction, and intention to recommend. Journal of Travel Research, 56(1), 41-54. https://doi.org/10.1177/0047287515620567

Richards, G. (2010). Tourism development trajectories - from culture to creativity. Revista Encontros Científicos, 6, 9-15.

Richards, G., \& Wilson, J. (2006). Developing creativity in tourist experiences: a solution to the serial reproduction of culture? Tourism Management, 27(6), 1209-1223. https://doi.org/10.1016/j.tourman.2005.06.002

Russell, J. A. (1980). A Circumplex model of affect. Journal of Personality and Social Psychology, 39(6), 1161-1178. https://doi.org/10.1037/h0077714

Salovey, P., \& Mayer, J. D. (1990). Emotional intelligence. Imagination, Cognition, and Personality, 9(3), 185-211. https://doi.org/10.2190/DUGG-P24E-52WK-6CDG

Sather-Wagstaff, J. (2011). Heritage that hurts: tourists in the memoryscapes of September 11. Series: Heritage, Tourism, and Community. H. Silverman (Series Ed.). London and New York: Routledge.

Sharpley, R., \& Stone, Ph. R. (Eds.). (2009). The darker side of travel: the theory and practice of dark tourism. Series: Aspects of Tourism. Ch. Cooper, C. M. Hall, D. J. Timothy (Series Eds.). Bristol: Channel View Publications.

Scherer, K. R. (1987). Toward a dynamic theory of emotion: the component process model of affective states. Retrieved from http://www.unige.ch/lettres/linguistique/Auchlin/MA-DiscoursProsodie/ Emotion_paralinguistique/Scherer_1987.pdf

Scherer, K. R. (2005). What are emotions? And how can they be measured? Social Science Information, 44(4), 695-729. https://doi.org/10.1177/0539018405058216

Stone, Ph. (2006). A dark tourism spectrum: towards a typology of death and macabre related tourist sites, attractions and exhibitions. Tourism, 54(2), 145-160.

Stone, Ph., \& Sharpley, R. (2008). Consuming dark tourism: a thanatological perspective. Annals of Tourism Research, 35(2), 574-595. https://doi.org/10.1016/j.annals.2008.02.003

Timm Knudsen, B. (2011). Thanatourism: witnessing difficult pasts. Tourism Studies, 11(1), 55-72. https://doi.org/10.1177/1468797611412064

TripAdvisor. (2018). About TripAdvisor. Retrieved from https://tripadvisor.mediaroom.com/US-about-us

Tumarkin, M. (2005). Traumascapes: the power and fate of places transformed by tragedy. Melbourne: Melbourne University Press.

Tunbridge, J. E., \& Ashworth, G. J. (1996). Dissonant heritage: the management of the past as a resource in conflict. Chichester: John Wiley \& Sons.

Velmet, A. (2011). Occupied identities: national narratives in Baltic Museums of Occupations. Journal of Baltic Studies, 42(2), 189-211. https://doi.org/10.1080/01629778.2011.569065 
Visit England. (2013). Domestic leisure tourism trends for the next decade. Retrieved from https://www. visitengland.com/sites/default/files/visit_england_report_print_tcm30-39493.pdf

Walls, A. R., Okumus, F., Wang, Y. (R.), \& Joon-Wuk Kwun D. (2011). An epistemological view of consumer experiences. International Journal of Hospitality Management, 30(1), 10-21. https://doi.org/10.1016/j.ijhm.2010.03.008

Weiler, B., \& Walker, K. (2014). Enhancing the visitor experience: reconceptualising the tour guide's communicative role. Journal of Hospitality \& Tourism Management, 21, 90-99. https://doi.org/10.1016/j.jhtm.2014.08.001

Wood, E., \& Latham, K. F. (2016). The objects of experience: transforming visitor-object encounters in museums. Oxon: Routledge.

Zatori, A., Smith, M. K., \& Puczko, L. (2018). Experience-involvement, memorability and authenticity: the service provider's effect on tourist experience. Tourism Management, 67, 111-126.

https://doi.org/10.1016/j.tourman.2017.12.013

\title{
KŪRYBINIO POŽIŪRIO RIBOS: DIRIGUOJANT EMOCIJŲ ORKESTRUI TAMSOJE
}

\author{
Ilze GRINFELDE, Linda VELIVERRONENA
}

\section{Santrauka}

Rytų Europos šalyse sovietinis periodas paliko daugybę nemalonių ir nepageidaujamų paveldo vietų, kurios yra jautrios, ịkrautos emociškai ir nelengvai komunikuojamos tiek vietinių, tiek turistų. Tokia vieta yra Valstybès saugumo komiteto pastatas, veikiantis kaip komunistinio režimo aukų muziejus Rygoje (Latvija). Tyrime aptariama pusiausvyra tarp kūrybiškumo ir autentiško paprastumo, modeliuojant lankytojų vietos potyrius tamsiojo turizmo objektuose. Tyrimo tikslas - paaiškinti lankytojų emocijas, lankantis Valstybės saugumo komiteto pastate Rygoje ir kūrybinio turizmo produkto dizaino vaidmenị sužadinant emocijas. Kaip pagrindiniu duomenų šaltiniu buvo pasinaudota lankytojų atsiliepimais apie jų apsilankymą Valstybès saugumo komiteto pastate TripAdvisor platformoje. Tyrimo rezultatai patvirtina, kad pasivaikščiojimas po Valstybès saugumo komiteto pastatą sukelia įsimintinų i̇spūdžių ir prieštarauja nuomonei, jog nauji šio tamsiojo turizmo produkto kūrybiškumo klodai patenkins ir pralinksmins klientą. Valstybės saugumo komiteto pastatas Rygoje - tai pavyzdys, kai kūrybinio turizmo produkto dizainas neturi reikšmingo poveikio lankytojų emociniams potyriams, nes pagrindiniai šaltiniai apie lankytojų patirtị yra aukštos kokybẻs turus vedančių gidų ir jų turimų gausių žinių, asmeninių istorijų, autentiškos atmosferos ir pastato interjero kuriamas spektaklis.

Reikšminiai žodžiai: tamsusis turizmas, kūrybiškumas, emocijos, turizmo produkto dizainas, lankytojo potyriai, lankytojo motyvacija. 